Annals of Warsaw University of Life Sciences - SGGW

Land Reclamation No 48 (4), 2016: 313-328

(Ann. Warsaw Univ. Life Sci. - SGGW, Land Reclam. 48 (4), 2016)

\title{
The method of determining surface water erosion influence on agricultural valorization of soils with usage of geoprocessing techniques and spatial information systems
}

\author{
BARBARA PRUS, TOMASZ SALATA, KRZYSZTOF GAWROŃSKI \\ Department of Spatial Management and Landscape Architecture, University of Agriculture in Kraków
}

\begin{abstract}
The method of determining surface water erosion influence on agricultural valorization of soils with usage of geoprocessing techniques and spatial information systems. The aim of the paper is to propose methodical solutions concerning synthetic agricultural analysis of production space which consists in combined (synthetic) - in spatial and statistical contexts - analysis and evaluation of quality and farming utility of soils in connection with soils erosive risk level. The paper is aimed at presentation of methodology useful in such type of analyses as well as demonstration to what extent the areas of farming production space being subject to restrictive protection are exposed to destructive effect of surface water erosion. Own factor (HDSP.E) was suggested, which is a high degree synthesis of soil protection in connection with degrees of surface water erosion risk. The proposed methodology was used for detailed spatial analyses performed for Tomice - the Małopolska rural commune (case study). The area model elaborated for the proposed methodology's purpose faced with soils mechanical composition allowed to make a model of surface water erosion in five-grade scale. Synthetic evaluation (product of spatial objects on numerous thematic layers) of quality and farming utility of soils and also zones of surface water erosion risk allowed to assign spatial distribution of HDSP.E factor (abbreviation of high degree of soil protection combined with erosion). The analyses enabled to determine proportional contribution of the most valuable resources of farming production space that are subject to soil erosion negative phenomenon.
\end{abstract}

Geoprocessing techniques used for the analyses of environmental elements of farming production space were applied in the paper. The analysis of spatial distribution of researched phenomena was elaborated in Quantum GIS programme.

Key words: soil agricultural quality and usability, multi-criteria spatial analysis, erosive factors, environmental aspect of planning of rural space, soil protection categories, erosive risk degrees, high degree of soil protection and erosion factor (HDSP.E factor)

\section{INTRODUCTION}

Farming production space areas in southeastern Poland according to Baran-Zgłobicka (2012) "are characterised by an extensive land use mosaic". The author explains the reason of such situation by claiming that "the lack of ownership's changes during the twentieth century has led to the preservation of family-based, extensive agriculture, characterised by very high land fragmentation with mosaic crops". Herzog (1998) defines such historically determined lands' structure "as a traditional agro forestry system". Land surface shape which is one of the main factors that influence erosion phe- 
nomena and also determines both the way of land's usage and cultivation difficulties is also not without significance (Cebecauer and Hofierka 2008, Koreleski 2008, Morgan 2009).

The research showed that Małopolska is the region which is characterized in Poland by the highest percentage of areas at risk of surface water erosion (Józefaciuk and Józefaciuk 1987, Wawer 2007, Drzewiecki et al. 2014). But on the other hand, it can be noticed that "a diverse land use mosaic is one of the most efficient methods of preventing soil erosion" (Boardman and Poesen 2006). However, the fact that "since Poland's accession to the European Union in 2004, local agriculture has received considerable financial assistance enabling significant changes in land use structure, including land consolidation" (Baran-Zgłobicka et al. 2010, Zgłobicki 2012) can be dangerous. The arable lands previously used in the form of lands mosaic and now concentrated in bigger acreages without balks and mid-field woodlots are more exposed to the surface water erosion phenomenon (Van Dijk 2007). Fedorowicz-Jackowski (1998) classifies erosive factors into two following categories: (A) factors relatively stable: erosivity of the climate, the erodibility of the soil, topography (slope length and slope angle); (B) factors susceptible to change: man's activities (land cover and land use, including conservation practices). The factors that belong to category A rarely change. However, category $\mathrm{B}$ gathers factors that change in the course of time. So, due to land usage modifications, degrees of soil erosion risks also change (Bakker et al. 2005, Prus and Salata 2013, Prus and Salata 2014). On one side, decrease of farm production and connected with it set-aside phenomenon of lands (Majchrowska 2013) which in turn are automatically covered by arborous and shrubby vegetation can be observed (Poławski 2009), whereas on the other hand, we observe acreage consolidation which causes elimination of balks, woodlots and mid-field shrubs (Pašakarnis and Maliene 2010).

Problems of proper management of environment resources should be taken into consideration already at the stage of spatial planning in communes (Staniak 2009, Gawroński et al. 2016). The Act of spatial planning and development puts special emphasis on waters management and protection of agricultural and forest lands. Even the legal definition of spatial order (the Spatial Planning Act 2003) describing that it is such a space shape which creates harmonious unity, says that it should consider habitat conditionings and demands. Habitat demands should be understood as environmental dangers of natural and anthropogenic origin. They constitute physiological barriers of spatial character which should be taken into account at the stage of preparing conditionings and development approaches of the commune's spatial development as well as the local plan of spatial development and 
also during planning distributions in the process of space development. The Spatial Planning Act (2003) imposes an obligation to consider conditionings that result in particular from the state of environment and farming production space while writing up planning conditionings elaborations. On the other side, environment and its resources protection rules and also trends and rules of farming production space shaping should be taken into consideration. That is why two research matters raised in the paper - both soil quality and usability in the area of farming production space and also erosive risk - have to be noticed and respected at the stage of local planning. Drzewiecki (2014) preparing the map of urgency grades of erosion control procedures for Małopolska province communes also presents such requirement. However, there are known cases of conflicts between various requirements of the local community, the representatives of which are self-government authorities that concern area usage functions and environment protection demands (Stachowski 2008). This conflict increases in a particular way when the area is subject to strong suburban pressure which especially affects communes (locations) in the immediate vicinity of the cities (Dylewski 2006, Poniży 2008, Mrozik et al. 2012).

The aim of the paper is to propose methodical solutions that concern synthetic analysis of farming production space which consists in combined (syn- thetic) - in spatial and statistical terms - analysis and evaluation of quality and agricultural usability in connection with soils erosive risk level. The paper is aimed at presentation of methodology useful in analyses of that type as well as showing to which extent areas of farming production space that are subject to restrictive protection are exposed to surface water erosion effect. Geoprocessing techniques and spatial information system Quantum GIS were used in the paper. The authors also proposed their own factor (HDSP.E) which makes high degree synthesis of soil protection in connection with risk degrees of surface water erosion. Proposed methodology was used to detailed spatial analyses performed for Tomice - the Małopolska rural commune (the case study).

\section{MATERIAL AND METHODS}

The surveys were carried out in the area of Tomice - the Małopolska rural commune $\left(41.5 \mathrm{~km}^{2}\right)$ located in Wadowice county. It includes six evidence premises: Lgota, Radocza, Tomice, Witanowice, Woźniki and Zygodowice. From the mentioned issues perspective, it is worth to point out that this commune is situated within the limits of the Carpathian Foothills. The Skawa river flows through its grounds dividing the commune into two parts. The eastern part (right-bank) includes the western frontiers of the Wieliczka Foothills which covers the Draboża Plateau. Even and wide hills cut with narrow and deep valleys' network 
(Lgota, Witanowice, Woźniki and Zygodowice places) are characteristic for this area. The left-bank western part, which includes two premises: Tomice and Radocza, is located in the area of the Silesian Foothills. It is the part that also covers the wide valley of meandering Skawa river. The bigger part of the commune's farming production space is occupied by fishing farms (Łopatecki 2011). At present, farming production space covers about $73 \%$ of the commune's area (agricultural land) which testifies to rural character of the commune's places. Forest areas as well as mid-field woodlots are the next $13 \%$ of the area. Watercourses and reservoirs occupy up to $5.3 \%$ of the area.

Within the frames of the most current analysis of erosive phenomena in Małopolska, the area of Tomice commune was qualified in three-grade scale of anti-erosive actions urgency: (1) very urgent, (2) urgent, (3) less urgent, to the second grade which means that it is the ground where preventive actions should be taken immediately (Drzewiecki et al. 2014). The very urgent degree of antierosive actions occurs when over $25 \%$ of agricultural land areas is subject to high grades of erosion, The urgent degree means that $10-25 \%$ of agricultural land of productive space is situated in the forth or fifth grade of erosive risk, whereas the less urgent grade means that only below $10 \%$ of farm lands is influenced by erosive phenomena actions (Józefaciuk and Józefaciuk 1975).

The research base concerning the analysis of farming production space state was constituted with data exposed in lands and buildings evidence for 2013. Farming production space resulted from selection of arable lands from the map of land use on the soil valuation-class areas.

Presenting in general proposed methodical solutions, two-stage tests were performed. Within the first stage, farming production space resources were comprehensively analyzed taking quality and agricultural usability and also connected with that lands protection into consideration. The second stage was connected with the analysis of risk grades for soils in danger of surface water erosion basing on the area numeric model and also knowledge of soils mechanical composition. In the end, the product of spatial objects located on ultimate layers from two stages was performed, receiving percentile collation of land protection categories confronted with risk grades of farming production space by surface water erosion.

To provide the first stage of proposed methodical solutions with details, the analysis of farming production space resources was performed to assess soils quality and agricultural usability by a combined analysis and evaluation of land classification categories as well as soils agricultural usability complexes. Soils production capabilities were assigned in the three-stage scale using a synthetic factor which enables farming production space valorisation: 


$$
s=\frac{\left(x_{1}+y_{1}\right) p_{1}+\left(x_{2}+y_{2}\right) p_{2}+\ldots+\left(x_{n}+y_{n}\right) p_{n}}{2\left(p_{1}+p_{2}+\ldots+p_{n}\right)}
$$

where:

$x$ - score for the first feature (soil-agricultural complexes);

$y$ - score for the second feature (land classification categories);

$p$ - area of respective plot's fragment;

$1, \ldots, n-$ responsible for the part of plots which was divided.

The next element of the first stage consisted in dividing of farming production space into three categories of protection (after Koreleski et al. 1998): the first group - the lands that are subject to special protection which are so-called unalterable resources, the second one areas with high grade of protection (their use for non-agricultural and non-forest purposes is permissible in case of lack of proper lands of the lowest category) and the third one which is composed of lands with moderated protection - the usage purpose of these resources can be changed into non-agricultural and non-forest.

The second element of the first stage of analyses consisted in testing of soil ground-water relations with reference to agricultural possibilities of production areas. The analysis was performed on the basis of soil-agricultural complexes knowledge.

The combined, synthetic analysis of above mentioned environmental ele- ments of agricultural production area allowed to classify the lands of Tomice commune and assign the following three categories of environmental and agricultural protection grades:

- lands with the highest grade of environmental and agricultural protection;

- lands with moderate grade of environmental and agricultural protection;

- lands with low grade of environmental and agricultural protection.

The assumption was accepted that the lands with the highest grade of environmental and agricultural protection are altogether singled out by the highest factor of soils quality and agricultural usability, optimal moisture content and also they are so-called national resources for the future. In turn, the lands that are distinguished by lowest grade of protection are not subject to any protection. The areas of the weakest production quality and defective moisture content were included there.

The second stage of analyses included preparing a model of potential surface water erosion on the basis of falls study which illustrates proper classes of slopes and mechanical composition of soil top layer. The falls study was generated with help of a kriging method using Gaussian curve function by means of SAGA GIS programme, on the basis 
of numerical land model prepared with resolution of $5 \mathrm{~m}^{2}$. Source data to generate the land numerical model came from two independent information sources SRTM in WGS84 system for the area of Southern Poland and from the topographic map in scale $1: 10000$ in 1992 system. In order to acquire data from the topographic map, all altitudinal points in the commune's area were digitalized together with the zone of $200 \mathrm{~m}$ beyond its borders.

Geoprocessing techniques were used for the purpose of cartographic spatial analyses. They are GIS operations used for processing data stored in GIS working spaces. Geographic objects overlaying, objects' selection and analysis, checking topology and data conversion are included in basic geoprocessing operations. Using geoprocessing methods, combined data that include information from three different categories (terrain falls, land classification categories and borders of lots/farms from the Lands and Buildings Evidence) were generated. Tools from the geoprocessing method which is processing geometric objects that have any spatial connection between each other were followed. In this case, the matrix product tool also called multiplication was used. It consisted in creating geometric objects that included the shared space $(\mathrm{A} \times \mathrm{B})$ of objects located on layers A (lots' borders) and B (land classification and usage borders).
The result of this operation was multiplied by layer C (falls' class) and the layer of soils moisture content (D).

These operations allowed to identify (separate) the areas which are showed in the present paper as HDSP factor (demonstrated in the next chapter). The formula is as follows:

$$
\operatorname{HDSP}=\{[(\mathrm{A} \cdot \mathrm{B}) \cdot \mathrm{C}] \cdot \mathrm{D}\}
$$

where:

A - lots/farms borders;

$\mathrm{B}$ - land classification and usage borders;

C - falls' classes;

D - soils moisture content categories.

Objects generated on the resultative layer of the water erosion model and defined as the smallest areas with homogenous surface conditions comprise three topic maps imposed on each other and related to the area usage, soils quality and terrain grade.

The product of resultative layers from two stages of the analysis allowed to generate the model illustrating categories of grounds natural and agricultural protection in connection (confrontation) with the five-grade scale of surface water erosion (Fig.1) referring to classification presented in papers by the Józefaciuk and Fedorowicz-Jackowski (Józefaciuk and Józefaciuk 1996, Fedorowicz-Jackowski 1998). 

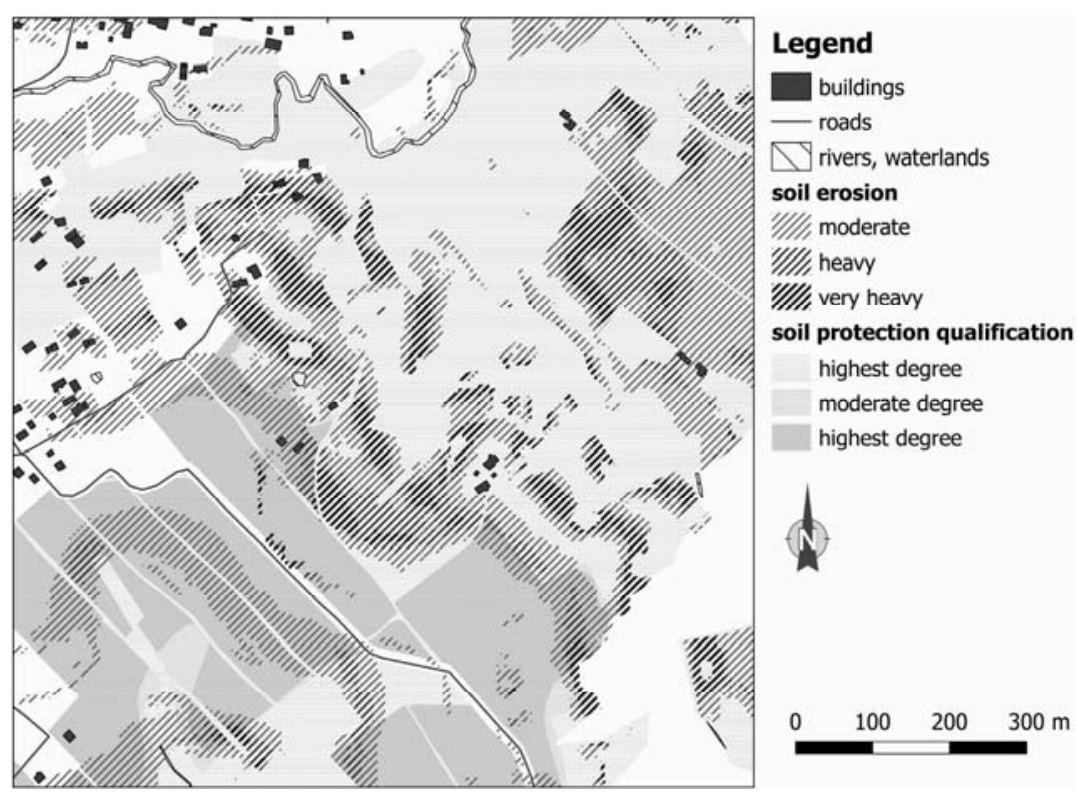

FIGURE 1. The spatial relationships of phenomena: of soil protected areas and high degrees of terrain falls (own study)

\section{RESULTS}

\section{The analysis of farming production space resources regarding their protection}

Performed surveys allowed to confirm the fact that spatial analysis, regarded as computer-aided is a very flexible and effective procedure to derive new information. Besides, GIS technology enables to visualize any result of the analysis and to compare results obtained in global, national, regional or local scales with each other (Fedorowicz-Jackowski 1998, Gotlib et al. 2007, Prus and Salata 2013, Prus and Salata 2014).

As was mentioned in the previous chapter, the first stage of the analyses based on synthetic estimation of farming production space chosen elements allowed to classify Tomice commune lands in three categories (Fig. 2). The first derived category included the grounds with the highest grade of natural and agricultural protection, the next one - with the average grade of protection and the third category of grounds defined as the areas with the low protection grade. The lands with the highest grade of protection are characterized by: the highest factor of soils quality and usability in terms of agriculture, optimal moisture content conditions and also the fact that they were classified as so called national resources for the future (Koreleski 1998). The lands classified to the category of the natural and agricultural protection average grade have in most cases high quality and usability evaluation, however, they are characterised by 


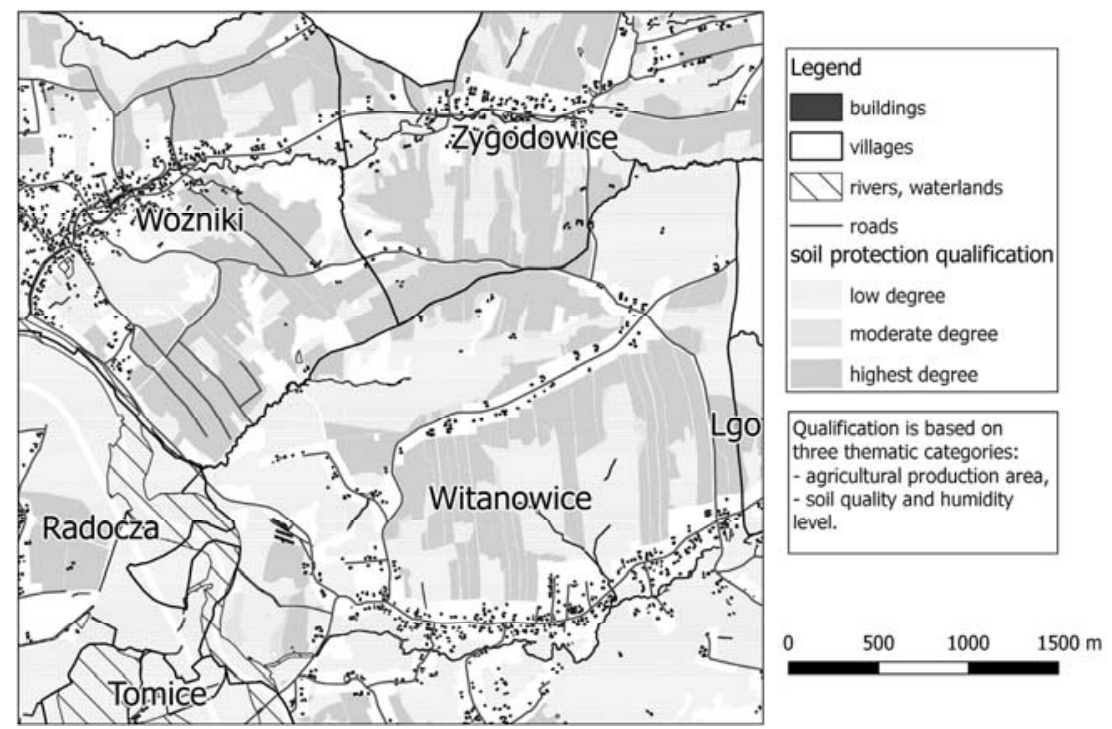

FIGURE 2. Valorization of resources of Tomice commune's farming production space (own study in Quantum GIS programme)

defective ground-water conditions. The lands of lower land classification categories which do not need restrictive protection belong here. The lowest classified category of lands of farming production space with respect to protection is the area of the weaker production quality which is characterised by improper air-water relations in the soils. This category can be the land resource for the future disposal for the purposes of investment politics of the commune's authorities (Koreleski 1998, Prus and Salata 2014).

Performed tests allow to state that about $21 \%$ of Tomice commune's area belongs to the category of the most valuable lands from the natural and agricultural points of view. Their significant percentage is located in places characterized by the extensively agricultural character, i.e. in Woźniki (38.7\%),
Zygodowice $(37.1 \%)$ and Witanowice (21.2\%). The smallest percentage of lands with the highest protection grade was reported in Lgota (9.7\%) and in turn in the communal places: Tomice (11.7\%) and Radocza (14.9\%). At the same time, it was stated that the second lands category being subject to the average protection is situated most often in Radocza, whereas the lowest percentage of the same category lands was noted in Woźniki. The lowest protection category of lands with weak agricultural and natural values is located in the significant area of Lgota, Radocza, Witanowice and Tomice places. It is guidance for the commune's authorities as this area is the provision of farming production space which in the future politics of the commune's authorities can be allocated to investment purposes (Staniak 2009). 
Further analyses take into account only the lands which are the most valuable from natural and agricultural points of view and these qualified to the first category of lands of farming production space.

\section{The analysis of surface water erosion}

The second stage of performed analyses included defining potential grades of threat of surface water erosion. The analysis indicates great level's diversity (grades) of erosive risk in the whole commune's area (Fig. 3). The tests show that the wide and flat area that includes the valley of meandering Skawa River is the land not covered by erosive risk. In general, $88.5 \%$ of agricultural lands of Tomice commune farming production space are at risk of surface water erosion which makes up more than $58 \%$ of the general area of the commune. Great erosive differentiation is, as surveys show, a characteristic feature of Małopolska Province (Józefaciuk and Józefaciuk 1996, Drzewiecki et al. 2014), where the object of research is located.

Almost $12 \%$ of farming production space in Tomice commune was classified as the area sensitive to erosion in the fourth and fifth grade (Fig. 4). Areas with the biggest risk of surface water erosion are located in Witanowice and Woźniki (over $11 \%$ of the general area in each place).

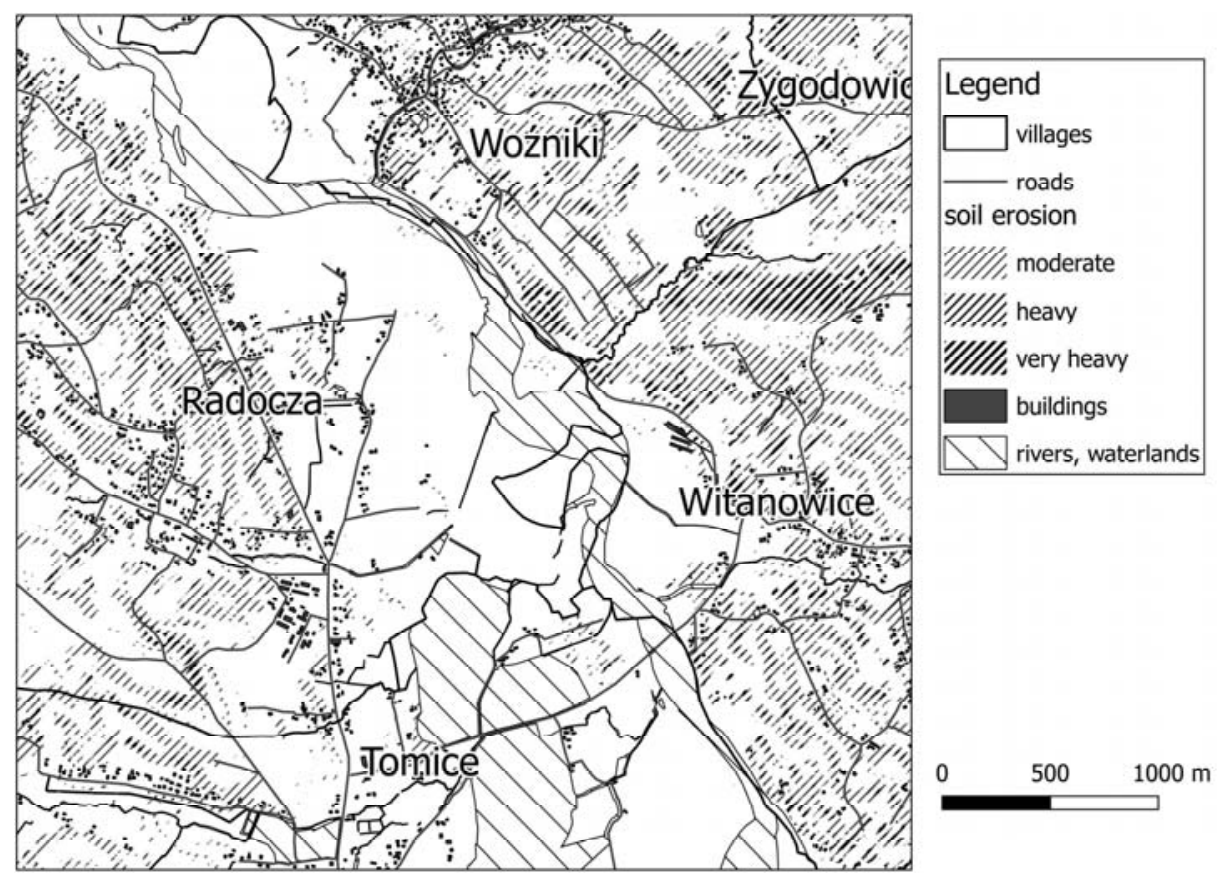

FIGURE 3. The spatial model of the potential threat of surface water erosion in Tomice (own study) 


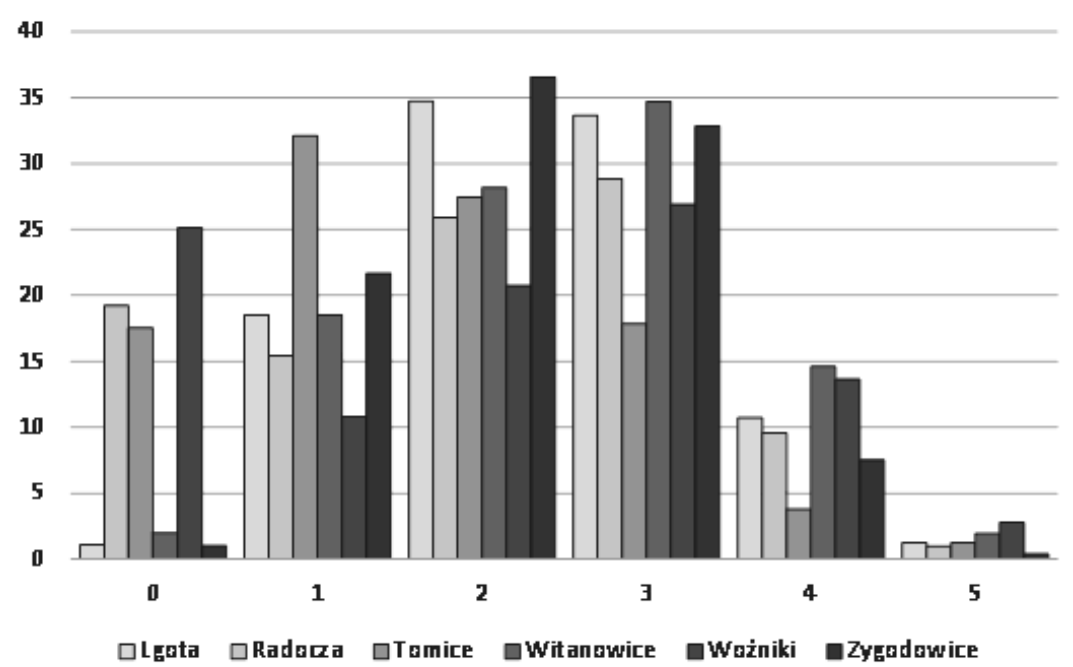

Grades of soil erosion risk: 0 - no erosion, 1 - very weak, 2 - weak, 3 - moderate, 4 -strong, 5 - very strong.

FIGURE 4. The percentage of the potential threat of surface water erosion in Tomice (own study)

The potential threat of surface water erosion in the highest grades appears in the commune's places with varied relief. Fourth and fifth grades of surface water erosion intensity levels need excluding arable lands from agricultural production as well as implementation of radical anti-erosive procedures, the way of usage change included.

\section{Synthetic analysis of farming production space resources confronted by potential area threat with surface water erosion, HDSP.E factor}

Complex analysis of environmentally valuable resources of farming production space confronted by the degrees of erosion risk allowed to determine HDSP.EX factor (high degree soil protection). This factor received additional identifier EX - which stands for soils with features to the high grade of their protection, however located in the area where surface water erosion takes place. Classifier $\mathrm{X}$ accepts values equal to the risk grades of surface water erosion. For example, HDSP.E0-2 indicates the lands of the high protection grade located in the erosive areas in the range of zero to second grade of erosion intensity grade (weak erosion).

Calculated HDSP.E factor for the tested commune demonstrates great diversities in individual places (Table). What is crucial, it determines which percentage of the most valuable resources of farming production space is endangered by the surface water erosion phenomenon in the third, fourth and fifth degree. Spatial distribution of HDSP.E factor in individual places of Tomice commune was presented in Figure 5. 


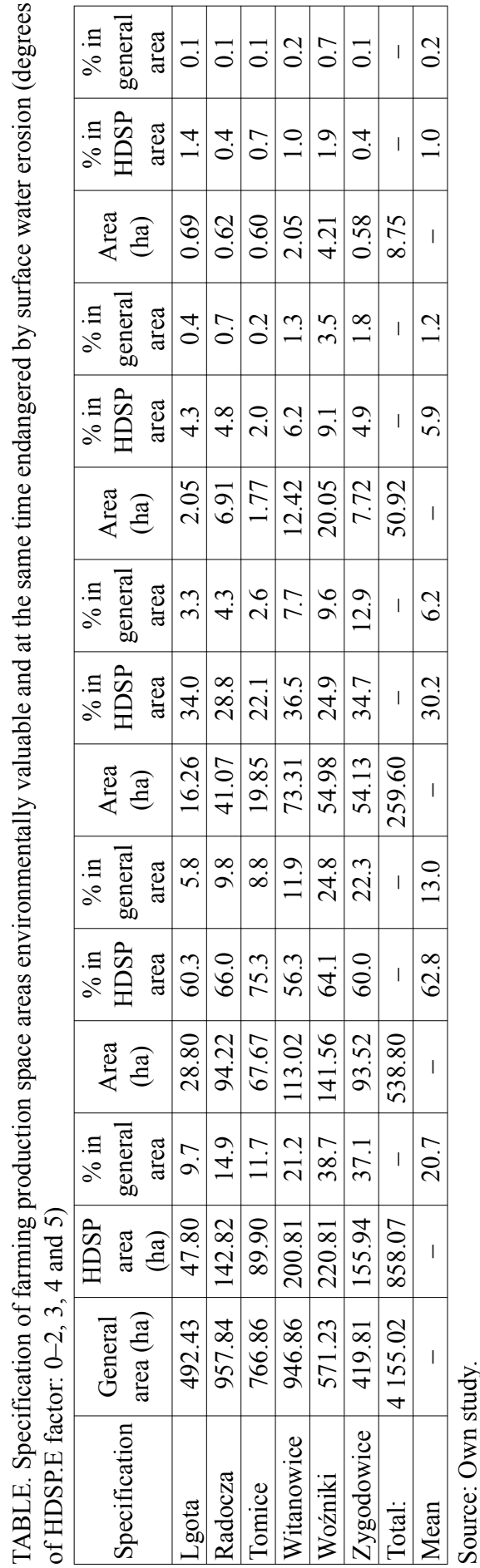

On the basis of the proposed HDSP. E factor's formula, spatial analyses were performed in the result of which it was stated that the valuable lands of farming production space are located in the areas with big surface water erosion threats (Table). In Tomice commune, about 63\% of the most valuable grounds are situated in the range of the effect of the first and second degrees of erosion which accounts for nearly $13 \%$ of the general area of the commune. About $30 \%$ of the valuable land is included in the third degree (moderate erosion) which is over $6 \%$ of the general commune's area. The fourth degree of surface water erosion is risky only for $6 \%$ of naturally valuable lands. The grounds of the most valuable farming production space in this erosion category are located in about $1 \%$ of the general area of the commune. The fact that only $1 \%$ of the most valuable resources which means about $0.2 \%$ of the general commune's area is affected by the fifth and the strongest surface water erosion is definitely satisfying.

In conclusion, it should be stated that obtained results confirm Drzewiecki's postulate (2014) about urgent necessity to consider areas endangered with surface water erosion for the antierosive programmes and also planning documents which are implementation of the local planning politics. As authors stress, it has particular meaning due to ground masses losses (Koreleski 2005), impediments for agriculture (Józefaciuk and Józefaciuk 1987, Stankiewicz and 


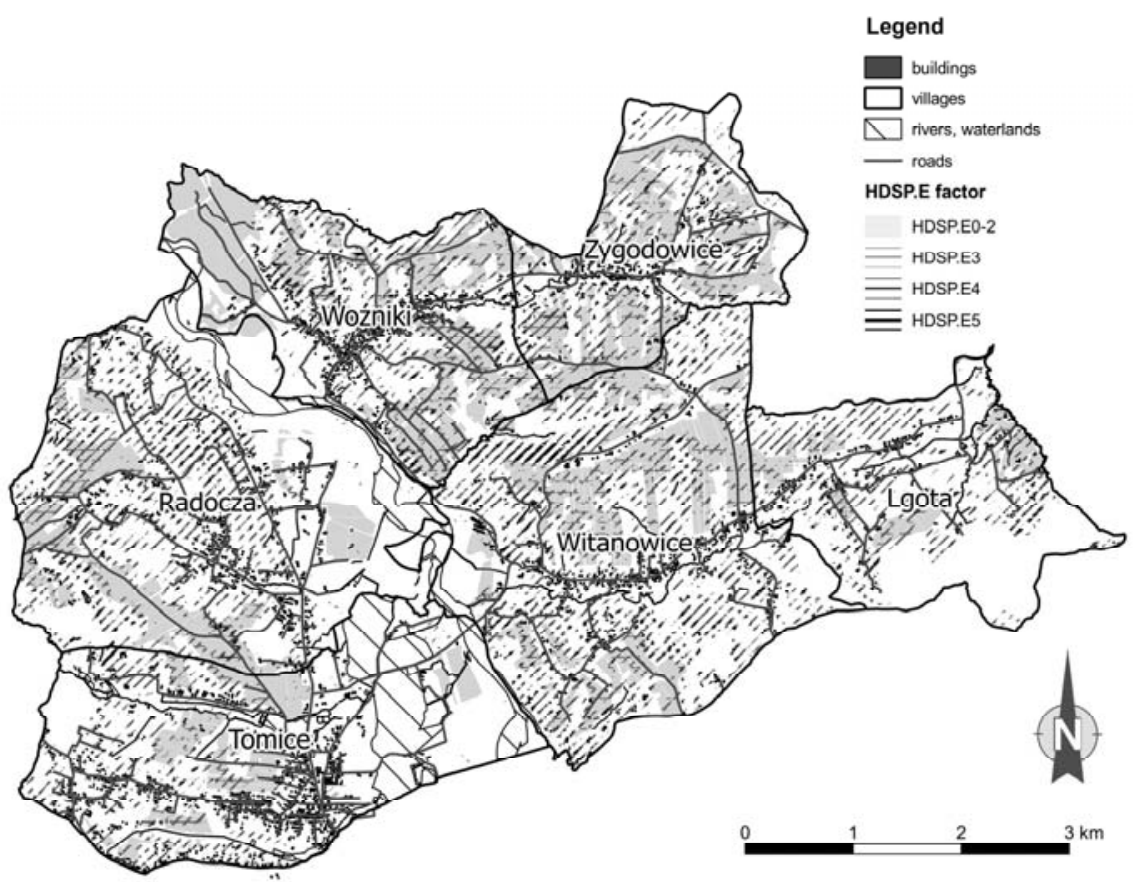

FIGURE 5. Spatial distribution of HDSP.E factor illustrating farming production space resources confronted with erosive risk degrees (own study)

Mioduszewski 2012), shaping of lands of agricultural usage (Mazur 2009) as well as the fact that Małopolska Province is evaluated as the most degraded area and at the same time endangered by anthropogenic influence on the environment (Fedorowicz-Jackowski 1998).

\section{SUMMARY AND CONCLUSIONS}

Concluding performed research, it can be stated that the issue that concerns combined quality analysis of agricultural soils usability and the level of surface water erosion intensity is especially important both in context of special protection of soils that compose national resources for the future and also from the point of view of lands economy led by self-government units authorities. In particular, these surveys can be an indication for the commune's authorities which areas that account for farming production space can be in future intended for investment purposes.

Submitted in the present paper method of defining surface water erosion influence on agricultural soils valorisation which was analysed in spatial terms needs using geoprocessing techniques as well as GIS systems which work very well in such type of analyses with spatial character. The analysis of natural and agricultural resources of production space faced with surface water erosion risk zones allowed to allocate areas that 
are valuable in terms of agriculture unalterable resources which are endangered by erosion. The areas of agricultural production space that are valuable naturally and agriculturally and at the same time should be particularly protected are situated mostly in the north part of the commune in Woźniki and Zygodowice places. In the south of the commune, in Lgota, Witanowice and Tomice locations, the big percentage of farming production space areas qualified to the lowest protection category can be observed. The reason of that situation can be soils that are slightly deficient in terms of air-water conditions that occur there as well as the low value of soils quality and agricultural usability factor. These soils belong to the weakest land classification categories in the commune.

Moreover, it can be stated that in case of changing agricultural areas into another purposes, spatial politics of Tomice commune should tend to assigning for investment purposes the area of farming production space qualified to the lowest natural and agricultural protection category (with moderated preventive activities) in the first place. Therefore, the grounds of such type can be defined as the ones the usage purpose of which can be changed. Because of that, they can be intended for investment targets in the future.

Nature protection has many aspects common with planning and spatial management problematic. One of them is usage of studies from the range of environment protection while preparing planning documents. The change of area purpose needs detailed analysis including areas' physiological conditionings identification and cataloguing which will make presumption and also, from the other hand, restrictions for the future lands management. Soils quality and agricultural usability together with terrain falls have got especially important meaning. The areas of farming production space and particularly these with high production opportunities are protected by the Act of protection of agricultural and forest grounds from 1995. At the same time, this document requires combating the erosion phenomenon if the visible results of its actions appear in the area that is used agriculturally. Moreover, nature protection problematic including farming production space protection takes place within particular agreements of local spatial planning acts which are conditionings and spatial management trends study and also the local spatial plan. Detailed environmental analyses are also carried out in so-called eco-physiological elaborations that are prepared for local spatial plans purposes. So it can be postulated that the problematic which concerns combined evaluation of agricultural quality of soils usability as well as surface water erosion intensity level should also be taken into consideration in above mentioned planning elaborations in spatial terms. 


\section{Acknowledgment}

Research was a part of project DS 3371/ /KGPiAK/2016 financed by the Ministry of Higher Education.

\section{REFERENCES}

BAKKER M.M., GOVERS G., KOSMAS C., VANACKER V., Van OOST K., ROUNSEVELL M. 2005: Soil erosion as a driver of land use change. Agric. Ecosyst. Environ. 105, 467-481.

BARAN-ZGŁOBICKA B., ZGŁOBICKI W. 2012: Mosaic landscape of SE Poland: should we preserve them? Agroforest Syst. 85, 351-365.

BOARDMAN J., POESEN J. 2006: Soil erosion in Europe: major processes, causes and consequences. In: J. Bordman, J. Poesen (Eds), Soil erosion in Europe. Wiley \& Sons, Chichester, 479-487.

CEBECAUER Y., HOFIERKA J. 2008. The consequences of land-cover changes on soil erosion distribution in Slovakia. Geomorphology 98, 187-198.

DRZEWIECKI W., WĘŻYK P., PIERZCHALSKI M., SZAFRAŃSKA B. 2014: Quantitative and Qualitative Assessment of Soil Erosion Risk in Małopolska (Poland). Supported by an Object-Based Analysis of High-Resolution Satellite Images. Pure Appl. Geophys. 171, 867-895.

DYLEWSKI R. 2006: Żywiołowe rozprzestrzenianie się miast. Narastający problem aglomeracji miejskich w Polsce [Irrepressible spreading of cities. Escalating problem of city agglomerations in Poland]. In: S. Kozłowski (Ed.), Problemy rozprzestrzeniania się miast w świetle doświadczeń krajów UE i USA [Problems of cities' spreading in the light of experiences of EU countries and USA]. KUL, PAN Kom. Człowiek i Środowisko, 27-38.

FEDOROWICZ-JACKOWSKI W. 1998: Assessment of Soil Erosion Risk in Poland. PHAREMulti-Country Environment Programme. MARS and Environmental Related Applications. Proc. 1994-1996 Results Conference, Bratislava, 10-11.12.1998, 67-77.
GAWROŃSKI K., PRUS B., SALATA T. 2016: Wybrane aspekty ekologiczne realizacji polityki przestrzennej na obszarach wiejskich - studium przypadku [Chosen ecological aspects of spatial planning in rural areas - case study]. Inf. Ekol. Ter. Wiej. PAN Kom. Tech. Infr. Wsi, Kraków 1, 1, 131-146.

GOTLIB D., IWANIAK A., OLSZEWSKI R. 2007: GIS. Obszary zastosowań [GIS. Use area]. Wyd. Nauk. PWN, Warszawa.

HERZOG F. 1998: Streuobst: a traditional agroforestry system as a model for agroforestry development in temperate Europe. Agroforest. Syst. 42, 61-80.

JÓZEFACIUK CZ., JÓZEFACIUK A. 1975: Komentarz do instrukcji w sprawie inwentaryzacji gruntów zagrożonych erozją [Comment to anti-erosion soil protection stocktaking instruction]. IUNG, Puławy.

JÓZEFACIUK A., JÓZEFACIUK Cz. 1987: Ocena wodnej erozji gleb terenów wyżynnych Polski na tle warunków przyrodniczo rolniczych [Estimation of water erosion of soils on Upland areas in Poland against the background of natural and agricultural conditions]. Roczniki Gleboznawcze 38, 51-58.

JÓZEFACIUK Cz., JÓZEFACIUK A. 1996: The erosion mechanism and methodological indicators for the research on erosion. Biblioteka monitoringu środowiska. Wyd. IUNG, Puławy.

KORELESKI K., GAWROŃSKI K., MAGIERA-BRAŚ G. 1998. Ochrona i kształtowania środowiska [Conservancy and cultivation of environment]. Wyd. AR w Krakowie, Kraków.

KORELESKI K. 2005: Wybrane zagadnienia przeciwerozyjnej ochrony gleb w świetle wymogów zrównoważonego rozwoju [Selected problems of antierosion soil protection in the light of sustainable development]. Acta Agrophysica 5, 49-55.

KORELESKI K. 2008: Wpływ czynników terenowych na natężenie erozji wodnej na przykładzie wsi górskiej [The influence of field factors on the intensity of water erosion exemplified by a mountain village]. Infr. Ekol. Ter. Wiej. PAN Kom. Tech. Infr. Wsi, Kraków 3, 5-12. 
ŁOPATECKI G. 2011: Gmina Tomice - krok po kroku... [Tomice Commune - step by step...]. Wyd. Urzędu Gminy Tomice, Tomice.

MAJCHROWSKA A. 2013: Abandonment of agricultural land in Central Poland and its ecological role. Ekologia 32 (3), 320-327.

MAZUR A. 2009: Wpływ procesów erozyjnych na kształtowanie terenów użytkowanych rolniczo [Influence of erosion processes on shaping the landscape on areas that are used by agriculture]. Teka Kom. Arch. Urb. Stud. Krajobr. - OL PAN, 64-70.

MORGAN R.P.C. 2009: Soil erosion and conservation. Wiley \& Sons, Chichester.

MROZIK K., BOSSY M., ZARĘBA K. 2012: Polityka przestrzenna gmin wiejskich na tle zmian zagospodarowania przestrzennego wynikających z suburbanizacji [Spatial policy in rural communes in relation to land use change resulting from suburbanisation]. Rocznik Ochrony Środowiska 14, 761-771.

PAŠAKARNIS G., MALIENE V. 2010: Towards sustainable rural developmnet in Central and Eastern Europe: applying land consolidation. Land Use Policy 27, 545-549.

POŁAWSKI Z.F. 2009: Zmiany użytkowania ziemi w Polsce w ostatnich dwóch stuleciach [Land use changes in Poland during last two centuries]. Teledetekcja Środowiska 42, 69-82.

PONIŻY L. 2008: Presja urbanizacyjna i jej wpływ na zmiany przestrzennej struktury użytkowania ziemi na wybranych obszarach podmiejskich Poznania [Urbanisation pressure and its effect on the spatial structure of land use in selected suburban areas of Poznań city]. Prob. Ekol. Kraj. 22, 335-342.

PRUS B., SALATA T. 2013: Analiza zasobów rolniczej przestrzeni produkcyjnej $\mathrm{w}$ polityce przestrzennej gminy Tomice [Analysis of resources for agricultural production area in land policy of District Tomice]. Infr. Ekol. Ter. Wiej. PAN Kom. Techn. Infr. Wsi, 3, 145-157 .

PRUS B., SALATA T. 2014: Influence of physiographic conditions on the quality of agricultural production area. Geomat. Env. Eng. 8, $4,55-65$.
STACHOWSKI P. 2008: Miejscowe planowanie i zagospodarowanie przestrzenne na przykładzie terenu w otulinie Parku Krajobrazowego „Puszcza Zielonka” [Local spatial planning and spatial management based on the example of the "Zielonka Forest" Scenic Park]. Rocznik Ochrony Środowiska 10, 575-592.

STANIAK M. 2009: Zrównoważony rozwój obszarów wiejskich w aspekcie środowiskowym [Sustainable development of rural areas in environmental aspect]. Woda-Środowisko - Obszary Wiejskie 27, 187-194.

STANKIEWICZ J., MIODUSZEWSKI W. 2012: Przestrzenna ocena niekorzystnych uwarunkowań gospodarowania na terenach rolniczych [Spatial assesment of adverse management conditions in agricultural areas]. Woda - Środowisko - Obszary Wiejskie 12, 239-256.

Ustawa z dnia 27 marca 2003 r. o planowaniu i zagospodarowaniu przestrzennym [The Spacial Planning Act]. Dz.U. 2003 nr 80, poz. 717.

Van DIJK T. 2007: Complications for traditional land consolidation in Central Europe. Geoforum 38, 505-511.

WAWER R. 2007: Erozja wodna aktualna w Polsce według województw w oparciu o Corine CLC2000 [Actual water erosion risk in Polish administrative regions based upon Corine Land Cover 2000]. Inżynieria Ekologiczna, 18, 104-105.

Streszczenie: Metoda określenia wptywu erozji wodnej powierzchniowej na waloryzację rolnicza gleb $z$ wykorzystaniem technik geoprocessingu oraz systemów informacji przestrzennej. Celem pracy jest propozycja rozwiązań metodycznych dotyczących syntetycznej analizy rolniczej przestrzeni produkcyjnej, polegającej na przestrzennej i statystycznej analizie oraz ocenie jakości i przydatności rolniczej gleb w powiązaniu z poziomem zagrożenia erozyjnego gleb. Praca ma na celu prezentację metodyki przydatnej do tego typu analiz oraz wykazanie w jakim stopniu obszary rolniczej przestrzeni produkcyjnej podlegające restrykcyjnej ochronie (o wysokiej jakości i przydatności bonitacyjnej) są narażone na niszczące działanie erozji wodnej powierzchniowej. W szczególności autorzy opracowali współczyn- 
nik (HDSP.E) stanowiący syntezę wysokiego stopnia ochrony gleb $\mathrm{w}$ połączeniu ze stopniami zagrożenia erozją wodną powierzchniową. Zaproponowana metodyka zastosowana została do szczegółowych, wielokryterialnych analiz przestrzennych wykonanych dla małopolskiej gminy wiejskiej Tomice (studium przypadku). Autorzy postawili sobie za cel dokonanie łącznej oceny mierzalnych zasobów rolniczej przestrzeni produkcyjnej, rozumianej jako grunty rolne zdefiniowane ustawą o ochronie gruntów rolnych i leśnych, oraz stref powstałych w wyniku analizy terenu pod kątem występowania zjawiska erozji wodnej powierzchniowej. Podstawowe analizy wykonano na podstawie informacji dotyczących jakości i przydatności rolniczej gleb oraz wynikających $\mathrm{z}$ badania tego zagadnienia kategorii terenów rolniczej przestrzeni produkcyjnej, które są najbardziej cenne pod względem rolniczo-przyrodniczym. Opracowany na potrzeby zaproponowanej metodyki numeryczny model terenu w konfrontacji ze składem mechanicznym gleb pozwolił na wykonanie modelu erozji wodnej powierzchniowej w pięciostopniowej skali. Syntetyczna ocena (iloczyn obiektów przestrzennych na wielu warstwach tematycznych) jakości i przydatności rolniczej gleb oraz stref zagrożenia erozją wodną powierzchniową pozwoliła na wyznaczenie przestrzennego rozmieszczenia współczynnika HDSP.E (skrót: ang. high degree of soil protection combined with erosion). Analizy umożliwiły określenie procentowego udziału najbardziej cennych zasobów rolniczej przestrzeni produkcyjnej podlegających niekorzystnemu zjawisku erozji gleb. Przeprowadzona analiza może stanowić podstawę do prawidłowego gospodarowania zasobami środowiska przyrodniczego $\mathrm{w}$ procesie miejscowego planowania przestrzennego, może także być wskazówką, w jaki sposób niwelować konflikty przestrzenne wynikające z funkcji użytkowania terenu w konfrontacji z potrzebami ochrony środowiska. W pracy zastosowano techniki geoprocessingu, które wykorzystano do analiz przestrzennych elementów środowiskowych rolniczej przestrzeni produkcyjnej. Analizę przestrzennego rozmieszczenia badanych zjawisk opracowano w programie Quantum GIS.

\section{MS received July 2016}

\section{Authors' address:}

Barbara Prus, Tomasz Salata, Krzysztof Gawroński

Katedra Gospodarki Przestrzennej i Architektury Krajobrazu

Uniwersytet Rolniczy w Krakowie ul. Balicka 253c, 30-149 Kraków, Poland

e-mail: b.prus@ur.krakow.pl rmtsalat@cyf-kr.edu.pl krzysztof.gawronski@ur.krakow.pl 